\title{
The Online Learning Process During the COVID-19 Pandemic Period in terms of the teacher's point of view
}

\author{
Nevrita \\ \{nevrita@umrah.ac.id\} \\ Raja Ali Haji Maritime University, Faculty of Teacher Training and Education, Biology Education Study \\ Program
}

\begin{abstract}
This study aimed to determine the online learning process from the teacher's point of view. The object of this research is 66 teachers spread across the Riau Islands Province with various educational units. This research instrument is an open questionnaire consisting of 5 indicators translated into ten questions and a closed questionnaire. This research is included in descriptive analysis. The research results all teachers have carried out the stages of the learning process starting from the use of technology, delivery of materials, learning activities, use of media, and the assessment process. Special attention is needed to learning activities because not all learning activities can be carried out during the learning process during the pandemic. The research concludes that most teachers have used technology; although material delivery cannot be maximized, it is assisted by giving assignments. Not all learning activities can be carried out. Most teachers have used several learning media, and teachers can carry out the assessment process despite all the limitations during online learning during the covid 19 pandemics.
\end{abstract}

Keywords: Online learning process. Covid-19 pandemic, teacher's point of view

\section{Introduction}

The emergence of the covid 19 outbreak in all corners of the world has changed in all fields. The pandemic impacted the community's economic sector that, from the financial aspect, had an alarming effect at the time and spread to the education aspect [1]. The government has issued many policies and circulars to regulate how the learning process can occur during the pandemic. The implementation of learning changes, usually students learn face-to-face in class, turning into online learning using applications. To regulate the learning process during the pandemic, the government has issued circular letter No. 3 of 2020 regarding preventing Covid 19 in education units. Such conditions cause the world of education to make changes and innovations in the learning process. Innovation in learning is done through online learning (on the network) or online. 
Today the learning process in Indonesia is still online learning. In its implementation, online learning is not as easy as imagined. Many problems and obstacles arise. These obstacles are both from the infrastructure supporting online education, the state of students, teachers, and parents. Barriers to infrastructure, especially the availability of electricity and internet access specifically for $3 \mathrm{~T}$ areas. Based on the Ministry of Education and Culture data, 18\% of primary and secondary education units do not have internet access, and about $3 \%$ of education units do not have electricity. The obstacle teachers face is the ability to use technology in online learning. Not all teachers master various learning platforms as the primary media to support online learning.[2] The obstacles faced by students are economic problems. Because of these obstacles, many students cannot participate in online learning because students do not have cellphones or laptops and cannot buy quotas.

Although learning is still online, the learning process should be appropriate and the same as offline learning. The difference is the implementation, and face-to-face learning are now online. Usually, teachers and students meet in classrooms. Now teachers and students meet virtually using an application. Learning that should be done face-to-face has turned into online learning. Online Learning, online or distance learning, which aims to meet educational standards by utilizing information technology using computers or gadgets that are interconnected between students and teachers as well as between students and lecturers so that through the use of technology, the teaching and learning process can still be carried out correctly.[3]

Circular number 4 of 2020 concerning the implementation of education policies in the emergency period of the spread (Covid-19), the second point is that the learning process from home is carried out with the following conditions: 1 . Learning from home through online learning to provide a learning experience for students. 2. Learning from home can be focused on life skills education regarding the pandemic. 3. Learning activities and tasks for learning from home according to individual interests and conditions. Online learning is a new challenge for teachers, which makes them have to master online learning media to carry out learning activities and be creative in the learning process so that learning objectives can be achieved optimally (Mantra, 2020).

Teachers play a significant role in the learning process. During the learning process, there is a reciprocal relationship between teachers and students. Teachers must have creative and innovative abilities in carrying out learning, hoping that the learning provided can develop students' potential optimally. During the pandemic, in delivering learning materials, teachers need to use appropriate learning strategies and methods. Teachers also need to implement the learning process by government rules and policies regarding learning during the pandemic. At this time, teachers are required to have the competence to support students during this pandemic. Still, competence is tough to do when online learning is implemented because there will be many problems in changing conditions, one of which is a lack of understanding from students in their Learning.[4] Through the various sources above, it is necessary to study how teachers carry out the learning process in the online period in the Riau Islands region. So the purpose of this study is to analyze the online learning process during the COVID-19 pandemic. 


\section{Methodology}

This research is a descriptive study, and the sample is teachers for all levels of education in the Riau Islands province. The total model is 66 teachers spread across the region. Closed and open questionnaires are instruments used in research with ten closed questions and two available questions. The research instrument was also strengthened by interviews conducted to find out the teacher's opinions about the implementation of online learning. Data analysis was carried out descriptively by analyzing the answers to the questions that the teacher had filled in. The study results would be presented, and diagrams made and then described in as much detail as possible.

\section{Results and Discussion}

The results and discussion of this study can be seen from the following explanation, which is described in detail with a narrative and analyzed for each item of the questionnaire that the teacher has filled out.

\subsection{Use Technology}

During the learning period, Due to the pandemic of 66 teachers who have filled out the questionnaire, it was found that $89 \%$ of teachers have used technology in learning. Although more than half of teachers have used technology, $2 \%$ of teachers have not used technology in education. This can be seen in the following figure 1.

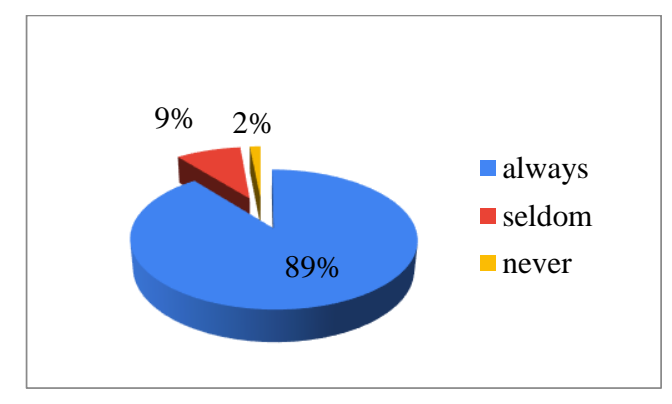

Fig 1. Technology Utilization

Based on the diagram above, it is clear that teachers have used technology in learning during the pandemic. This statement follows what was stated by Salsabila et al. $(2020,194)$. Technology plays a significant role in learning, especially in the Covid-19 pandemic situation. Technology also provides convenience to teachers and students in conducting distance learning, making it easier to assess students. Although it is not done face-to-face, utilizing various platforms such as Google document as a medium in conducting online discussion forums, submitting exams through google 
forms, and procuring quizzes through websites or applications. This is in line with the research results which states that after Covid-19, institutional education has wholly depended on e-learning infrastructure facilities such as the internet, electronic devices, applications, etc. LMS.[5] The current online learning period requires teachers to master technology, and teachers must be innovative towards developing media. Teachers must master and update the methods applied because learning methods during a pandemic are different from pre-pandemic methods if teachers are creative in choosing the appropriate method. It is hoped that students will not get bored.[6] So for the use of technology, the teacher has done things that follow the needs of learning and learning situations that do require technology in education.

\subsection{Duration of learning time}

During online learning, the time that the teacher uses to carry out the various learning processes is outlined in the following figure 2 .

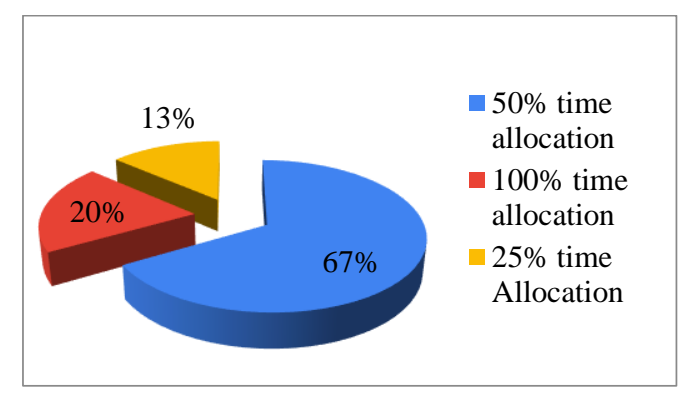

Fig 2. Time Allocation for one meeting

It can be seen from the diagram above that from the three specified answer choices and can be seen that the teacher stated that during online learning, used only half of the time used. When learning offline, Some teachers say that the time needed for the learning process is only a quarter of an hour. You can imagine how the teacher has to design learning in such a short time, and the teacher must also think about it so that the students can absorb the subject matter well in such a short time. In everyday learning conditions with the available time, students cannot grip the material well and with limited time. The lack of understanding of the material and the short time to complete the task causes students to find it challenging to do the tasks given. Lack of learning time raises anxiety when conditions return to average students cannot learn new material well because they do not understand the previous material.[7]

The limited learning time also influences the delivery of material during the learning period of the pandemic. This is illustrated in the diagram of the results of distributing questionnaires that have been filled in by the teacher, which can be seen in the following Figure 3 . 


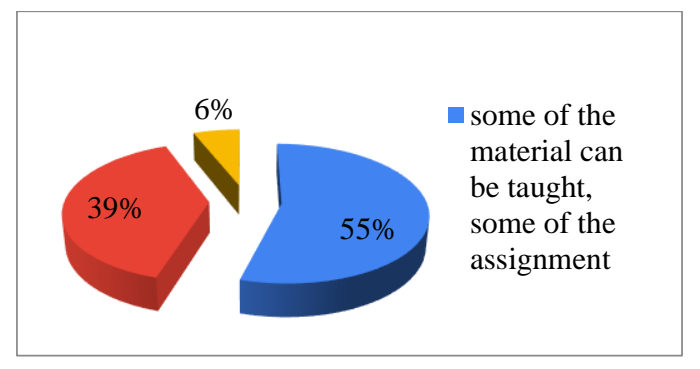

Fig 3. The Integrity of the material being taught

The questionnaire results showed that during the pandemic learning period, the delivery of material could be done only partially. Students were given the task of completing the delivery of material that was not optimal. No one could deliver material for some teachers and only told the student to read books and do assignments. Even during the pandemic, some teachers could provide the material in its entirety because some of the teachers provided material using learning videos. This condition is very influential in terms of the limited material that can deliver; not all material being produced, of course, will reduce students' absorption of the material. Suppose the teacher completes the understanding of the material by giving assignments. This causes not all students to complete the task well because students do not understand and understand the material. Less conducive learning situations during online learning cause teachers to have difficulty transferring the subject matter to students, then students have difficulty understanding the subject matter, especially calculation material.[8] So for the learning process related to the short duration of learning can deliver not all material. Hence, teachers need to think of other techniques so that material that has not been conveyed can be given in different ways, including providing assignments and making learning videos for students. For this, it is necessary to pay attention to all parties to continue motivating and supporting teachers so that teachers continue to try to deliver the material despite the limited learning time.

\subsection{Implementation of learning activities}

To determine the implementation of learning during the pandemic consists of preliminary activities, core activities, and closing activities. The performance of learning activities during this pandemic can be seen in the figure $\mathbf{4}$ below. 


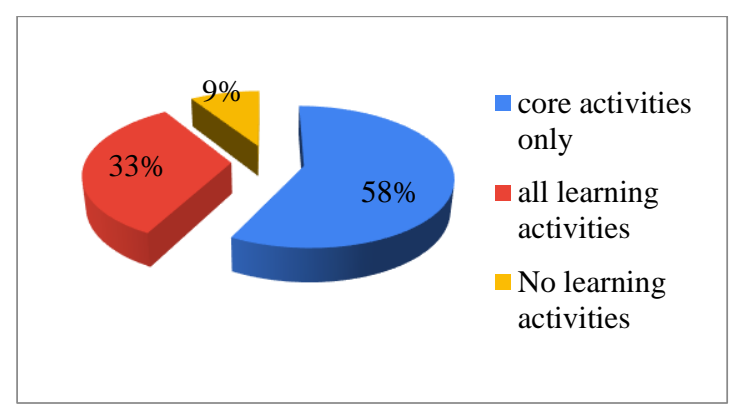

Fig 4. Implementation of learning activities starting from preliminary activities, core activities and closing activities

Data obtained from the questionnaire show that most teachers cannot carry all learning activities out and only core activities. Some teachers said that all learning activities could be carried out in their entirety. Few of the teachers stated that there were no learning activities that could carry out because the teacher only gave assignments. If the learning activities cannot be carried out consisting of preliminary activities, core activities, and closing activities, the teacher cannot fully implement the learning strategy. If can do only the core activities, the teacher cannot know the students' initial readiness and interest in learning. Closing activities are also not carried out so that teachers cannot measure the achievement of learning objectives. Teachers also will not know the completeness of learning in one basic competency.

\subsection{Utilization of learning media during the pandemic The}

Use of learning media is significant in the learning process. Through learning media, teachers can increase students' motivation, interest, and enthusiasm for learning. During a pandemic, the use of teaching media must also be a priority. Through the figure 5 below, it can be seen the use of teacher learning media during the pandemic.

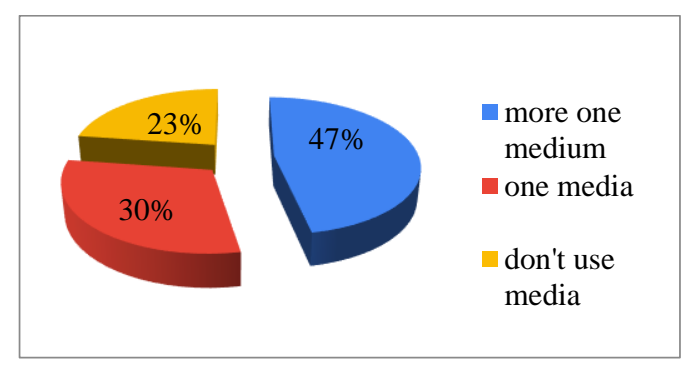

Fig 5. Media Use 
During online learning, the teacher has used learning media. This can be seen from the diagram above. It turns out that most teachers have used various media during the learning process. Some teachers use only one medium, and some do not use media at all. The teacher does not use the press because the duration of learning is short, and the teacher does not have time to use the media. When viewed from this condition, the teacher stated that they could not increase students' learning motivation to the maximum because the use of media that had not maximized was an obstacle for the teacher to convey the material. If the material is not delivered optimally, the learning objectives are also challenging to achieve. This can be seen from the opinion of Siti Khulsum.[9] The use of learning media is systematic and innovative to achieve practical learning objectives and is adapted to the learning characteristics to be carried out.

A variety of teaching media and educational platforms have emerged and encourage and demand the professionalism and skills of teachers in carrying out teaching tasks to students. The benefits are not only felt by teachers but also by students and parents who can directly feel the benefits of teaching media. Learning media and educational platforms may be an alternative solution in learning for the continuity of learning in every academic unit.[10] The use of teaching media applied by teachers during this pandemic can be seen from the following figure 6 .

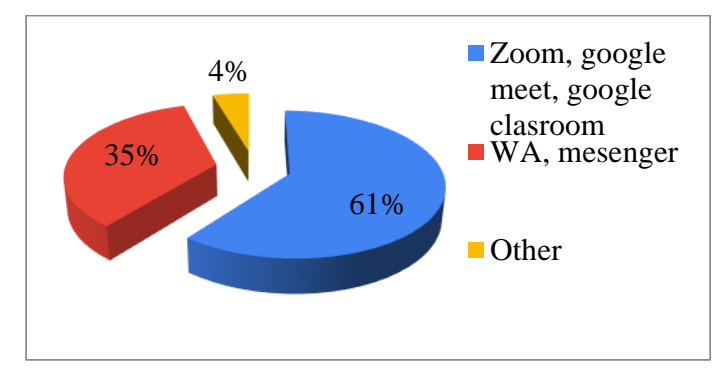

Fig 6. Technology Used

The figure above shows that most teachers use the Zoom, Google Meet, and Google Classroom applications. This third use is the teacher's choice. There are several advantages of using zoom. First, zoom can be downloaded for free and allows up to 100 participants. Second, you can schedule lessons through the Schedule feature. Third, you can record and save videos while learning is taking place. Fourth, Zoom Cloud Meeting can work on Android, iOS, Windows, and Mac devices that can replace.[11] While google meet is an option, this is supported by the research results which state that with google meet, teachers can see and ensure students' readiness and activeness by activating on camera the teacher can ensure students are attentive and ready to participate in learning.[12]

Although teachers have used several media in their learning, some teachers' opinions in the outermost areas of online learning significantly interfere with the learning process. The limitations of the internet network cause teachers to not be able to teach optimally, and students cannot learn 
effectively. Another rule is that most of the students do not have cell phones. Another opinion is that online learning causes students to be lazy to study. Their cell phones are used for playing, not for education. Through this explanation, we can conclude that although teachers have used technology in their learning by using several non-paid applications that are easily accessible and easy to use, obstacles are still found in their implementation, especially for teachers who teach in remote and outer islands. For the use of media, the teacher also understands and understands the learning process. The teacher must try to use various media to overcome the delivery of material with the media used and selected.

\subsection{Assessment Process During the Pandemic.}

\subsubsection{Assessment during the learning}

The assessment process in the 2013 curriculum, which is still valid today in education, prioritizes assessing attitudes, knowledge, and skills. The processed results of the questionnaire obtained through the answers from the teacher are shown in the figure 7 below.

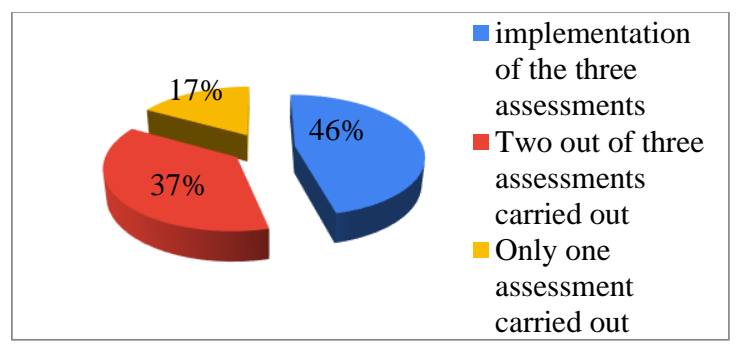

Fig 7. Implementation of aspects of assessment, assessment of knowledge, attitudes and skills

During the learning process during the COVID-19 pandemic, there were still teachers who did not carry out the three assessments. For knowledge assessment, almost all teachers carry out this assessment in their learning. Still, cannot carry evaluation of the skills out because the teacher's reason is the limited ability of teachers to carry out simple practicum using simple equipment available in the environment. Even though according to May et al, the tools and materials needed for the implementation of certain practicums have been prepared, which are the easiest to find in the surrounding environment, this is done so that teachers can still assess aspects of student skills even with remote observation.[13] The collection of practicum performance results can usually be in the form of photos or videos. Through this opinion, teachers can still conduct skills assessments even though the conditions are still pandemic.

Meanwhile, the teacher can still carry the attitude assessment through the timeliness of students to enter online learning. The teacher can also assess the teacher's responsibility for completing the 
tasks given. However, the questionnaire results show that there are still teachers who only make one assessment in learning.

\subsubsection{Daily pandemic}

Tests during knowledge assessment are carried out by teachers in the form of tests and other conditions. The implementation of difficulties during the learning process also needs to consider allocating time for collecting these assignments. If the teacher does not provide a test, the teacher can also conduct an assessment in other forms. To find out the implementation of the evaluation in online learning can be seen in the following figure 8 .

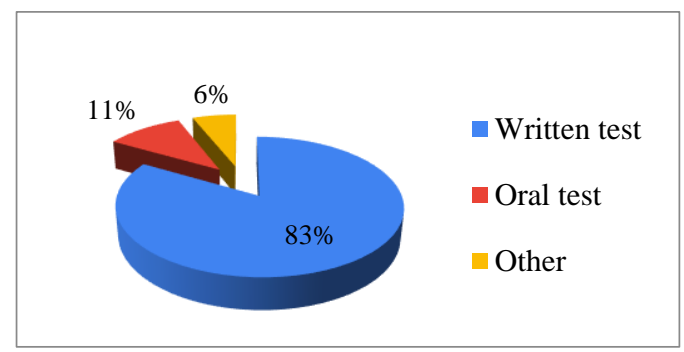

Fig 8. Daily Form

Through the diagram above, we can see that almost all teachers give daily tests to students; very few teachers use oral tests. Very few teachers provide other forms of assessment. The teacher grants daily trials to measure the achievement of learning objectives. The examinations carried out can also be used to measure individual mastery and classical mastery of students. The results of the analysis from the questionnaire show that the teacher has carried out daily assessments. For daily inspections, teachers can be categorized as good in carrying out daily checks.

Daily tests that students have completed are continued with daily test corrections. The process correction carried out by the teacher for the teacher's implementation of the correction process during this pandemic can be seen in the following figure 9.

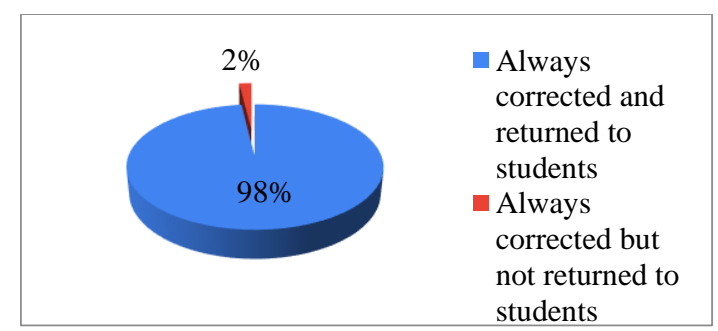


Fig 9. Daily Test Correction

From the results of data analysis seen from the diagram above, almost all teachers corrected students' daily tests and returned the correction results to students. Even though in a pandemic condition, the teacher has carried out the task as well as possible, the pandemic is not an obstacle for the teacher to carry out the mission of correcting students' daily tests, as feedback the teacher also returns the results of the test to students. This is following the suggestion put forward in improving student learning outcomes. A teacher should return student test results to help students develop their abilities to succeed in improving student learning outcomes.[14]

The return of test results will be better if the teacher has given a value or comment. If students are informed about the daily test results, they will focus more on materials that are still not mastered by students. If the student's daily test results are not returned, the student does not know the material concept that is still not understood. Still producing test results is a beneficial process, especially for students. Students can directly find out their level of ability in mastering the material taught by the teacher and will spur students to improve learning outcomes further.[14] Teachers who do not provide feedback in the form of corrections to student work papers are detrimental and damage students' learning motivation. Teachers who are lazy to correct student work make students wait. It is not uncommon for students to become annoyed with the teacher, even charging the teacher for their work papers. Finally, some students tend to lose the desire to see the value they get from the results of the exercises they have done.[15]

\subsubsection{Giving assignments during the pandemic}

Assigning assignments during online learning is still done, considering that the delivery of material cannot be maximized. Giving lessons is an alternative to support increasing student understanding of the material. The opinion expressed by Agus that giving homework assignments is currently a strategy in distance learning that requires students to study at home in learning natural sciences, students do more experiments or practice accompanied by parents and teachers provide material to be reviewed. And done by students during the pandemic, students cannot practice or experiment with classmates like in groups.[16] The assignment by the teacher can be seen in the following figure $\mathbf{1 0 .}$ 


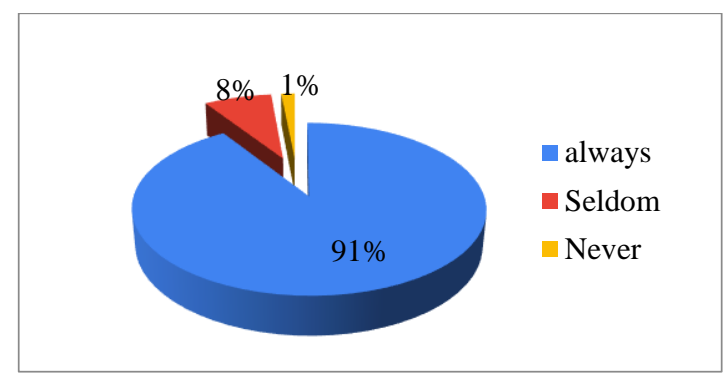

Fig 10. Assignment

Most teachers have given assignments to students; only a few teachers rarely do not give lessons. The teacher offers daily assignments as a means of obtaining student grades. Giving assignments online can run smoothly and stably if assisted by an internet network connection to access gadget devices.[17] Based on the research results for giving this assignment, the teacher has carried out his main task very well because to help students understand the material presented in a limited time, giving assignments is an alternative so that students can understand the subject matter well.

\section{Conclusion}

Based on the research findings, it concluded that during online learning during the covid 19 pandemics, from five indicators that developed into ten questions, it was finished that: The teacher used technology during education. In a short time, I could deliver some of the material, some of it with assignments. Only core activities can be carried out; preliminary and final activities cannot be carried out optimally. The learning media used by teachers vary, even though some teachers only use one medium. Knowledge assessment, daily tests, and assignments can be carried out. Barriers to online learning experienced by teachers who teach in remote and outermost areas are 1) not all students have cellphones, 2) unavailability of electricity, 3) complex internet networks, 4) the inability of parents to provide quotas.

Acknowledgments

Acknowledgments at conveying to the 66 teachers in the Riau Islands Province who are happy to help the authors obtain data for the purposes of this research.

\section{References}

[1] Taufik R. Pembelajaran Daring di Era Covid-19. Accessed at https://osf.io/7bfhk/download. 2020. (21 September 2021 at 15:00) 
[2] Albert EP. The Concept Of Online Learning Is Based On A Scientific Approach. Purwodadi Central ; Java Group: CV Sarnu Untung: 2020

[3] Roida P, Yuni F. Analisa Pemanfaatan Teknologi Informasi Dalam Pembelajaran Jarak Jauh Di Tengah Pandemi Virus Corona Covid-19. Journal of Information System, Applied, Management, Accounting, and Research. 2020.Vol 4 (2) : 30-36.

[4] Jajat S. Teacher Competence in the Covid-19 Pandemic Period. Semarang: Journal of Economic and Business Research.2020. Vol 13(1): 100-109

[5] Askar G, Abdullah MAA, Ika NQ. The Role Of E-Learning Infrastructure And Cognitive Competence In Distance Learning Effectiveness During The Covid-19 Pandemic. The Horizon of Education.2021. Vol 40 (1): 81-91

[6] Indah W, Itsni PR. Peranan Guru Dalam Pembelajaran Daring Pada Masa Pandemi Covid - 19. Indonesian Journal of Teacher Education.2020. Vol 1 (4): 159-164

[7] Dwi HO. Factors Triggering Student Anxiety in Conducting Online Learning in the Time of the Covid-19 Pandemic. Scientific Journal of Batanghari University Jambi (JIU BJ). 2020. Vol 20 (2): 541-544

[8] Napsawati. Analisis Situasi Pembelajaran IPA Fisika dengan Metode Daring di Tengah Wabah COVI-19. Jurnal Pendidikan Fisika dan Terapannya. 2020. Vol 3 (1): 6-12

[9] Siti Kulsum SHK. Pemanfaatan Media Pembelajaran, Inovasi di Masa Pandemi Covid-19. 2021. Vol 3 (4): 2149-2158

[10] Yasni A. Online Learning Media during the Coronavirus Disease. Journal of Islamic Religious Education (JPAI). 2020. Vol 02 (1): 49-56

[11] Junita M, Dini F. Efektivitas Penggunaan Aplikasi Zoom Sebagai Media Pembelajaran Online Pada Mahasiswa Saat Pandemi Covid-19. Jurnal Communio: Jurnal Ilmu Komunikasi. 2020. Vol IX (2): 1630-1640

[12] Piki SP, Nova, Annisa SR. Penggunaan Aplikasi Google Meet dalam Menunjang Keefektifan Belajar Daring Masa Pandemi Covid-19 di SMA Negeri 3 Pekanbaru. Pedaagogi: Jurnla Ilmu Pendidikan. 2021.Vol 21 (1): 45-50

[13] May WJ, Wahyu BS, Wahono W. Case Study of the Application of Science Learning Assessment during the Covid 19 Pandemic. Pensa e-Jurnal: Science Education. 2021.Vol 9 (3): 336-355

[14] Gesia MU. Pengaruh Pengembalian Hasil Tes Sejarah Terhadap Hasil Belajar Siswa Kelas VII SMP Negeri 6 Ambon. Jurnal Pendidikan Sejarah. 2016. Vol 5 (2): 86-92

[15] Andy S. Perbedaan Hasil Belajar Matematika Siswa Yang Diberi Umpan Balik Berupa Angka Saja Dengan Umpan Balik Berupa Angka Disertai Komentar. Jurnal Agmasu Research. 2012. Vol 1 (1): 85-92

[16] Agus DM. Efektivitas Pemberian Tugas Pekerjaan Rumah Ilmu Pengetahuan Alam Saat Pandemi Covid-19 Siswa Kelas IV Sekolah Dasar Negeri Basirih 8 Kecamatan Banjarmasin Selatan Kota Banjarmasin. Pahlawan Jurnal Pendidikan, Sosial dan Budaya. 2021. Vol 17 (1): $56-61$

[17] Maria WD, Wayan G, I Ketut A. Pengaruh Metode Pemberian Tugas Dalam Masa Pandemi Covid-19 Terhadap Peningkatan Prestasi Belajar Siswa. Journal of Mahasisya Pendidikan. 2021. Vol 3 (1): 1-8 